\title{
Generic Green Skills in Teaching and Learning: Meaning and Implementation
}

\author{
Mohd Zolkifli Abd Hamid*, Zainudin Hassan, Mohd Safarin Nordin, Yusri Kamin, Noor Azean Atan, \\ Nornazira Suhairom
}

School of Education, Faculty of Social Sciences and Humanities, Universiti Teknologi Malaysia, Malaysia

Received October 1, 2019; Revised November 22, 2019; Accepted December 3, 2019

Copyright@2019 by authors, all rights reserved. Authors agree that this article remains permanently open access under the terms of the Creative Commons Attribution License 4.0 International License

\begin{abstract}
The burgeoning of green economies has sparked the development of green skills, primarily to fulfil the demanding requirement of green-collar employees. Human resources equipped with specific generic green skills will become a catalyst to penetrate the green job market. On the principle that skills can be shaped through education and training, a qualitative study was conducted using in-depth interviews with senior academics from the School of Education, of a local university in southern Peninsular Malaysia. The interview data were transcribed and analysed using NVivo. The findings showed that generic green skills are additional skills which complement existing generic skills and focus on conserving and maintaining the quality of the environment. Pertaining to that, embedding generic green skills in teaching and learning activities can be carried out through the ingenuous use of Information and Communications Technology (ICT) which involves digital skill, internet technology and electricity saving consumption. Furthermore, additional studies of generic green skills are required to contribute to sustainable development.
\end{abstract}

Keywords Human Resource, Generic Green Skills, Green Jobs, Teaching and Learning, Generic Skills

\section{Introduction}

\subsection{Human Capital and Generic Skills}

If the mast of a country's development lies in its economy, then sustainable economic growth relies heavily on its human resources. With respect to that, an indicator of national competitiveness is the quality of its human resources (Mahfud, Jati \& Mulyani, 2017). This aligns with Amiruddin and Zainudin (2015) who mentioned that human resources are acknowledged as the most crucial capital in influencing progress and development. Amiruddin, Ngadiman, Abdul Kadir \& Saidy (2016) further assert that the quality of human resource development is the most pivotal capital contributor to a nation's success. In terms of terminology, human capital is more comprehensive than human resource (Zaini Ujang, 2009). Also, 'human' comprises the entire human faculty consisting of its physical, intellectual and spiritual dimensions. Zaini Ujang describes the ultimate development of human capital to produce more qualified, skilful and efficient workers (Rahmah Ismail, 2008). Producing competent human capital requires not only high technical skills but also non-technical skills otherwise known as generic skills.

Various terms were used to portray generic skills. For instance, Sodemann (2008) referred to it as non-technical skills, employability skills, necessary skills and key qualification, while Robles (2012) named it soft skills. Others called it emotional intelligence (Nicolaide, 2002 in Nik Safiah Nik Ismail, 2010) and skills of workability (Mohamad Sattar and Rose Amnah, 2010). These skills may differ depending on the context and situation. In any case, it refers to all skills other than technical skills possessed by employees. According to Lippman, Ryberg, Carney \& Moore (2015), soft skills are a broad set of skills, attitudes and personal qualities which enable employees to manage their work environment effectively, work comfortably with other employees, perform a task well and focus on achieving the targeted goals. They further explained that these skills are widely used and complement other fields of education such as technical, vocational and academic.

In a green job context, Arasinah Kamis, Ridzwan Che Rus, Mohd Bekri Rahim, Faizal Amin Nur Yunus, Normah Zakaria \& Haryanti Mohd Affandi (2017) define green skills as the technical skills, knowledge, values and attitudes required by the workforce to develop and support social, economic and environmental sustainability. This definition covers three areas of employees’ living. However, according 
to Zaki Kamsah (2004), there are two major issues faced by today's employers. The first is to get good employees, and the second is to train them. Good employees are those who receive specialised training in their field, are competent and have outstanding and competitive work discipline, coupled with an exceptional personality.

\subsection{Green Job and Generic Green Skills}

In line with the green economy development agenda, the proliferation of green technology has contributed to the fourth industrial revolution and has led to the growth of generic green skills, especially in green jobs. In tandem with that, Agus Setiawan (2017) concluded that green jobs require workers with generic green skills. Asnawi and Djatmiko (2015) contended that current and future employment across sector and industry would focus on green jobs.

Green jobs are closely related to green technology and contribute to green economic prosperity. Green technology refers to eco-friendly, clean and environmental-friendly technology designed to preserve nature and natural resources (Ramlee Mustapha and Siti Shuhada Mat Abu, 2014). To ensure the success of green jobs, employees must be equipped with well-founded generic green skills. With that, generic green skills will be employers' key criteria in hiring and recruiting new employees (Mohd Zolkifli Abd Hamid, Yusri Kamin, Dayana Farzeeha Ali \& Mohd Azlan Latib, 2014). Ahmad Nabil Md. Nasir, Muhammad Khair Noordin \& Nurliana Matam (2015) referred to generic green skills as any form of employment that has the potential to engage in eco-friendly activities comprising 3R (Recycle, Reuse and Reduce) practices. These features are included in Pavlova's (2011) definition of generic green skills, which are environmental awareness, attitude and willingness to learn about sustainability, issues and challenges in the development of sustainability. The 3R's refer to activities which contribute gradually towards sustainability. In the same vein, generic green skills could best be described as the effort to preserve good environmental quality through the implementation of the 3R's.

Meanwhile, the Swinburne University of Technology through its Education for Sustainability Hub (2014) has listed generic green skills at work as minimising resource use, reducing emissions of greenhouse gases, recycling, using environmentally friendly products and conserving nature. These skills are related directly to generic green skills. At the same time, Maclean, Jagannathan \& Panth (2018) listed generic green skills as environmental awareness, energy efficiency, water conservation, waste reduction and waste management.

Other than generic green skills, some scholars incorporate technical skills with generic green skills, which led to the emergence of Green Skills, which might confuse many people. Callan (2003) specified that there is confusion about the wide range of terms being used. Green skill is a skill that brings together elements of knowledge, technical and non-technical skills, capabilities and attitudes needed to produce sustainable human resources (Mohd Shahril Mohd Hassan, Azman Hassan \& Ruslina Awang, 2016). Following that, they classify the green skill elements into 'soft' green skills and 'hard' green skills. According to them, soft green skills are non-technical skills, which include attitudes and capabilities while hard green skill is the technical knowledge and skills required to achieve sustainability goals. Altogether there are 20 elements of 'soft' green skills and 13 elements of 'hard' green skills (Mohd Shahril Mohd Hassan et al., 2016). Since the primary motive of generic green skills is towards preserving the environment, some academics call it environmental-friendly skills (Asnawi and Djatmiko, 2015).

\subsection{Embedding Generic Skill in Teaching and Learning}

As specified by Yassin, Hasan, Amin \& Amiruddin (2008), all undergraduate programmes offered in public higher learning institutions in Malaysia are now required to incorporate generic skills in the curricula. This reinforces the fact that generic skills can indeed be inculcated in teaching and learning. Generic skills can be shaped through teaching and learning designed by lecturers using diverse teaching methods, which may result in strengthening various aspects of generic skills (Rosini Abu and Fitrisehara Kazilan, 2008). Moreover, giving a full lecture or demonstrating the skills is not proven to be methods of developing the skills among students (Zaki Kamsah, 2004). In higher education, lecturers play a crucial role to enhance students' employability skills (Mohamad Rasidi Pairan, Shahrul Azmir Osman, Nur Hazirah Seth, Ahmad Nabil Md Nasir, Mohd Rustam Mohd Rameli, Hanifah Jambari, Nurul Aini Mohd Ahyan \& Muhammad Nasir Nasrul, 2018). Concurrently, students must be responsible for ensuring that the necessary skills are fully mastered in preparation for the job market. As emphasised by Suarta, Suwintana, Fajar Pranadi Sudana \& Dessy Hariyanti (2018), nowadays, employees are anticipated to have additional skills other than occupationally related technical skills. In other words, generic skills are an 'intrinsic-licence' to secure exceedingly viable green jobs.

\section{Methodology}

To explore this issue in-depth, a descriptive study was adopted using a qualitative approach. Raw data from in-depth individual interviews with respondents were collected using a semi-structured interview protocol. The interview data were then transcribed manually and analysed using NVivo. Three levels of coding (open, axial and selective) processes were conducted to identify the themes that provide answers to the research questions. Respondents were senior lecturers from the School of Education, Faculty of Social Sciences and Humanities in a Malaysian research 
university located in the southern part of Peninsular Malaysia. All respondents have a Doctor of Philosophy majoring in technical, vocational and engineering education, specialising in either building construction, mechanical engineering, electric and electronic engineering or living skills.

\section{Findings}

\subsection{The Meaning of Generic Green Skills}

Most of the respondents opined that generic green skills are supplementary skills focusing on maintaining a good quality environment. According to one respondent:

"I think generic green skill is generic skill too, nothing new, more or less is almost the same. The only difference is.... this (generic green skills) is more towards an effort to keep the environment in good quality. For example, awareness and habit of switching off the table-top computer is also a generic green skill too. Moreover, this practice could save electricity. Instead of letting the computer off by itself, why not we simply switch off the power and take off the power plug." (respondent A)

Referring to the above statement, in essence, generic green skill refers to the awareness and attitude on energy saving. It is also evident that academics will ask students to switch off the computer as well as the LCD (Liquid-Crystal Display) projector. However, an insensible habit is leaving the power plug attached to the power socket. This will permit the non-stop flow of electric current to the computer and LCD, which will gradually increase the energy consumption.

Another question was raised. 'What are generic green skills all about' which evoked this feedback from other respondents:

"As we all know, ...actually...this is a generic skill too, but the difference is that this kind of skill tends to the practice of electricity saving and preserving the environment through 3 R's activities.” (respondent B)

This statement suggests that generic green skills are not new. It is the zealous effort to sustain a healthy environment by practising the concept of Reduce, Reuse and Recycle, together with the austerity that measures against the use of electricity.

A detailed inquiry produces a more precise explanation:

"Generic green skills are a non-technical skill which is very much needed by future workers, where with these skills, they can help environmental sustainability and save energy consumption." (respondent $C$ )

Closely related to the meaning of generic green skill, one of the respondents linked it to soft skills (non-technical skills) and the endeavours to heighten good environmental quality show that the term of sustainability has to do with the meaning of generic green skill. It shows that sustainability could be developed and maintained through the 3R's (as mentioned by respondent B). It is a term used commonly in discussions on environmental sustainability. At the same time, reducing the use of energy resources is also considered part of generic green skills.

In the context of students at higher learning institutions, by observing the rules and regulations related to cleanliness and energy-saving practices, they contributed to a healthy conducive learning environment and reduced the university's spending on electricity. These practices can be equally defined as implementing green practices in the learning environment and as such, contribution towards the accomplishment of the Occupational Safety and Health Administration (OSHA). These green practices are consistent with generic green skills among undergraduates and graduates who will be entering the job market.

Another respondent elucidated:

"I think, generic green skill is simply another version of generic skill..... sometimes they refer it as employability skill or soft skill. However,...the apparent difference between these skills is...generic green skill is more towards keeping a good environment. So...I think...anything goes with the aim to preserve the environment is called generic green skills". (respondent D)

Another respondent agreed that generic green skills are skills which correspond with a clean environment. It indicates that efforts (preserve the environment) to curb pollution concern environmental prosperity and also relate to generic green skills.

\subsection{Instilling Generic Green Skills in Teaching and Learning}

"During teaching and learning, I use paperless activities whereby students are asked to hand over their paperwork or assignments via on-line mode, which is likely in tandem to the needs of e-learning. So... to enable students to submit their paperwork, assignment and whatever it is... they must know how to use the computer as a medium of interaction, not only with lecturers but also among their friends. Lately, I noticed that many students use their savvy handphones to capture my notes on the screen, share among their friends through WhatsApp group... to facilitate group discussion. Even...lecturers were asked to use QR (Quick Response) technology to take students' attendance. To make it happen, all students need to have a smartphone...and...of course...this is a good move to inculcate generic green skill among them. (respondent E)

Fast-growing technology also affects teaching technology in the lecture room. The implementation of e-learning in the lecture room is an example of a holistic approach to 
teaching and learning. More state-of-the-art teaching aids, coupled with the use of digital devices, are becoming standard compared to the conservative and traditional approach to teaching and learning. This development forces students to become more skilful in digital and internet technology. In other words, ICT literacy is extremely important for both students and academics. Indirectly, advancement in digital technology compels students and academics to master the skill of using various smartphone applications.

Dexterity in using smartphone indicates that the use of technology in education aligns with green practices and will enrich generic green skills. The ability to make full use of smartphones could be classified as being digitally literate and can be considered part of the generic green skill. As asserted by Pavlova (2009), technology in education is seen as a means for developing knowledge, skills, attitudes and values (these are all generic skills) that allow students to optimise their flexibility, adoptability and adaptability for their future employment.

The competency of using computers and software, together with internet technology is an essential factor in ensuring the success of e-learning. This strengthens the reason why information technology is categorised as part of generic green skill as it does not use paper to communicate (for instance handing over assignments or reports to lecturers) and indirectly reduces the use of printer ink. In doing so, it contributes to developing a low-carbon society and reinforces environmental sustainability.

\section{Discussion}

The green concept which comprises economy, technology, job and generic skill, has fascinated many industry players as well as academics. At the same time, in confronting the challenges of the Fourth Industrial Revolution, the quality of future human resources should be taken seriously. While it is believed that the number of human resources might reduce, it is imperative to produce excellent workers equipped with generic green skills.

Students of higher learning institutions are the future of 'human capital reservoir', and as such, there is an expectation that upon entering the labour market, they would be able to transform the economy towards a green economy. To ensure this, students must be groomed with generic green skills. This responsibility is entrusted to the academics. To this end, it would be beneficial for studies to explore how academics perceive generic green skills.

The findings showed that academics perceived generic green skills as an addition to the existing generic skills coupled with a prudent attitude and belief in preserving a healthy environment. Any non-technical skills which focus on maintaining environmental sustainability such as minimising environmental degradation and efforts to save energy consumption are considered part of generic green skills. This finding is corroborated by the conclusion by Mohd Zolkifli Abd Hamid, Yusri Kamin \& Zuhairi Che Mohammad (2016) that any activity that mitigates environmental degradation and energy saving could be defined as green practices and leads indirectly to environmental sustainability.

Generally, when someone mentions 'green', they tend to associate it with the environment and a manifestation of generic green skills and practices. It means that generic green skills are generic skills which become a catalyst for green environment. Indirectly, this answers the question raised by the European Centre for the Development of Vocational Training (CEDEFOP, 2009) of whether there is a need to create new generic green skills or enhance the existing generic skills. Obliquely, Mohd Zolkifli et al. (2014) concluded similar findings. Thus, generic green skills are the betterment of existing generic skills.

Pertaining to the innovative practices in lecture rooms such as the extensive use of computers and LCD projectors, e-learning implementation and the awareness of electricity saving are some examples of inculcating generic green skills in teaching and learning. Concurrently, students are encouraged to use smartphones. To record students' attendance in the lecture room, QR codes were used extensively. This indicates that the ingenuity of students in the use of smartphone showed that digital skill is another complement to generic green skills.

It is well acknowledged that generic skills can be taught, learned (Zaki Kamsah, 2014; Nik Safiah Nik Ismail, 2010; Wentling, 1987) and nurtured. Similarly, Dayue Fan (2016) asserted that the green concept could be instilled in students through various teaching and learning activities. To make certain the effectiveness of instilling generic green skills among students, it is of utmost importance that academics have a clear and accurate understanding of generic green skills. In a nutshell, generic green skills are pertinent to green practices, and green practices are the interpretation of self-awareness.

In addition to the above discussion, Zelin (2016) proposed that the best way to instil generic green skills is through green education. She further elaborated that green education is important for cultivating a workforce of the future equipped with the knowledge of ecologically friendly and sustainable technologies. In a similar vein, Pavlova (2016) underpinned Zelin's statement about green education. According to her, green education combined with training programmes plays a significant role enabling workers to participate in the green economy and that educational reform may be the most important tool in determining the direction of future greening and sustainability (Baumgarten and Kunz, 2016).

\section{Conclusions}

Although generic skills are widely known, generic green 
skills have yet to receive broad coverage. For these shortcomings, education is said to be the best medium to disseminate knowledge, understanding, awareness and practice of generic green skills among students of higher education. Before it can be executed, it is beneficial if we can examine academics' views on the inculcation of green generic skills in the lecture room. Generic green skills are auxiliary skills which focus on conserving, preserving and maintaining a quality environment. In other words, it is an 'add-on' to the existing generic skills. With regards to teaching and learning activities, generic green skills are closely related to the practice of e-learning, electricity saving, the use of smartphones, digital technology and application of ICT. To sum up, inculcating generic green skills in teaching and learning would enhance future manpower employability, especially in the green job labour market. Academics, as well as students of higher learning, must have a high awareness of generic green skills and practice it accordingly. Further studies are encouraged to reveal more details and explicit understanding of generic green skills implementation among academics and university students.

\section{Acknowledgements}

This research was funded by Fundamental Research Grant Scheme (FRGS), Ministry of Education Malaysia under vote number 4F841. Special thanks go to the Research Management Centre of Universiti Teknologi Malaysia for managing the activities of this research.

\section{List of Abbreviations}

CEDEFOP: European Centre for the Development of Vocational Training

ICT: Information and Communications Technology

LCD: Liquid-Crystal Display

OSHA: Occupational Safety and Health Administration

QR: Quick Response

3R: Recycle, Reuse and Reduce

\section{REFERENCES}

[1] Agus Setiawan 2017. Identification of Green Skills Acquisition in Indonesian TVET Curricula in AIP Conference Proceedings, Vol. 1887, Issue 1.

[2] Ahmad Nabil Md. Nasir, Muhammad Khair Noordin \& Nurliana Matam 2015. Green Employability Skill Terhadap Pelajar Di Kolej Vokasional Johor. In Kelestarian Pelaksanaan Kolej Vokasional Di Malaysia. Skudai, Johor: UTM Press.19-38.

[3] Amiruddin HH, Ngadiman N, Abdul Kadir R \& Saidy S 2016.
Review of Soft Skills of TVET Trainees From the Malaysian Advanced Technology Training Center (ADTEC). Journal of Technical Education and Training, Vol. 8, (1):14-24.

[4] Amiruddin MH \& Zainudin FL 2015. The Effects of a Mastery Learning Strategy on Knowledge Acquisition Among Aboriginal Students: An Experimental Approach. International Journal of Vocational Education and Training Research. Vol. 1(2): 22-26.

[5] Arasinah Kamis, Ridzwan Che Rus, Mohd Bekri Rahim, Faizal Amin Nur Yunus, Normah Zakaria \& Haryanti Mohd Affandi 2017. Exploring Green Skills: A Study on the Implementation of Green Skills Among Secondary School Students. International Journal of Academic Research in Business and Social Sciences. Vol. 7 (12): 327-345.

[6] Asnawi R \& Djatmiko IW 2015. A Challenge of Vocational Education for Preparing Green Employment. The International Journal of Technical and Vocational Education, Vol. XI (2):154-160.

[7] Baumgarten K \& Kunz S 2016. Re-thinking Greening TVET For Traditional Industries in Asia - The Integration of a Less-skilled Labour Force Into Green Supply Chains. The Online Journal for Technical and Vocational Education and Training in Asia (6).

[8] Callan VJ 2003. Generic Skills: Understanding Vocational Education and Training Teacher and Student Attitudes. NCVER: SA, Australia.

[9] CEDEFOP 2009. Skills for green jobs: Developing a low-carbon economy depends on improving existing skills rather than specialised green skills,in worksyop on Green skills, green jobs: opportunities for the South West Low Carbon Economy, (Briefing Note). South West Observatory Skills and Learning, UK.

[10] Dayue Fan @ David 2016. A Survey Report on Greening in Higher TVET in China. The Online Journal for Technical and Vocational Education and Training in Asia (6).

[11] Lippman LH, Ryberg R, Carney R \& Moore KA 2015. Key Soft Skills That Foster Youth Workforce Success: Toward A Consensus Across Fields. Workforce Connections, Child Trend Publications \#2015-24.

[12] Maclean R, Jagannathan S \& Panth B 2018. Education and Skills for Inclusive Growth, Green Jobs and the Greening of Economies in Asia: Case Study Summaries of India, Indonesia, Sri Lanka and Viet Nam. Singapore: Springer Open.

[13] Mahfud T, Jati BK \& Mulyani Y 2017. Soft Skill Competency Map for the Apprenticeship Programme in the Indonesian Balikpapan Hospitality Industry. Journal of Technical Education and Training. Vol. 9(2): 16- 34.

[14] Mohamad Rasidi Pairan, Shahrul Azmir Osman, Nur Hazirah@Seth, Ahmad Nabil Md Nasir, Mohd Rustam Mohd Rameli, Hanifah Jambari, Nurul Aini Mohd Ahyan \& Muhammad Nasir Nasrul 2018. Identification of Employability Skills Among Technical and Vocational Education Master Student in University Tun Hussein Onn Malaysia (UTHM): A Case Study. The Turkish Online Journal of, Art and Communication. Special Edition, September 2018: 862-865.

[15] Mohamad Sattar Rasul \& Rose Amnah Abdul Rauf 2010. 
Pembangunan Alat Ukur Tahap Kemahiran Kebolehdapatan Kerja. Serdang, Selangor: Penerbit Universiti Putra Malaysia.

[16] Mohd Shahril Mohd Hassan @ Abdul Ghani, Azman Hassan \& Ruslina Awang@ @audzi 2016. Penerokaan Elemen Kemahiran Hijau. in $1^{\text {st }}$ National Conference on TVET: Meeting the Challenge of Innovation in TVET. Faculty of Technical and Vocational Education, Batu Pahat, Johor: Penerbit UTHM. 273-280.

[17] Mohd Zolkifli Abd Hamid, Yusri Kamin, Dayana Farzeeha Ali \& Mohd Azlan Latib 2014. Kemahiran Generik Hijau: Eksplorasi Kajian Kepustakaan. Paper presented in International Seminar on Global Education in UKM, Bangi, Selangor on 24-25 February 2014.

[18] Mohd. Zolkifli Abd. Hamid, Yusri Kamin \& Zuhairi Che Mohammad 2016. Tekonolgi Hijau Dalam Pelestarian Alam Sekitar: Perspektif Ahli Akademik Pendidikan Teknikal dan Vokasional, in Penerapan Kemahiran dan Gaya Pembelajaran Dalam Pengajaran dan Pembelajaran. Skudai, Johor: Penerbit UTM, 79-90.

[19] Nik Safiah Nik Ismail 2010. Soft Skills: The What, The Why, The How. Bangi, Selangor: Penerbit Universiti Kebangsaan Malaysia.

[20] Pavlova M 2009. Technology and Vocational Education for Sustainable Development: Empowering Individuals for the Future. Netherlands: Springer.

[21] Pavlova M 2011. Economic Competitiveness and Green Skills Development: Issues And Concerns For Research. Paper presented in The International Conference, Green Korea. Sept. 15, 2011, Seoul, South Korea.

[22] Pavlova M 2016. Regional Overview: What is the Government's Role in Greening TVET? The Online Journal for Technical and Vocational Education and Training in Asia (6).

[23] Rahmah Ismail 2008. Modal Manusia Dan Prestasi Industri. Bangi, Selangor: Penerbit Universiti Kebangsaan Malaysia.

[24] Ramlee Mustapha \& Siti Shuhada Mat Abu 2014. Perspective of Technical Students on Green Technology: A Case Study in a Malaysian Public University. in Proceedings of $10^{\text {th }}$ Conference of AASVET (Asian Academic Society for Vocational Education and Training), Daito-Bunka University, Tokyo. 194-205.

[25] Robles MM 2012. Executive Perceptions of The Top 10 Soft Skills Needed in Today's Workplace. Business Communication Quarterly, 75(4): 453-465

[26] Rosini Abu \& Fitrisehara Kazilan 2008. Kesedaran Kemahiran Generik Dalam Kalangan Pelajar Pendidikan Keguruan. in Pendidikan Teknikal \& Vokasional: Suatu Perspektif Umum. Serdang, Selangor: Penerbit Universiti Putra Malaysia. 183-196.

[27] Sodemann K 2008. Soft Skills: Important in the World of Work and How to Train Them. Asia Pacific Technical HRD Conference and Career Expo '08, 6 - 7 August 2008, Kuching, Sarawak.

[28] Suarta IM, Suwintana IK, Fajar Pranadi Sudana IGP \& Dessy Hariyanti NK 2018. Employability Skills for Entry Level Workers: A Content Analysis of Job Advertisements in Indonesia. Journal of Technical and Training, Vol. 10(2): 49-61.
[29] Swinburne University of Technology 2014. Green Skills, Green Jobs - What's the Difference? www.swinburne.edu.au/ncs/efshub/greenskill.html Downloaded on 27 Jan. 2015

[30] Wentling RM 1987. Teaching Employability Skills in Vocational Education. Journal of Studies in Technical Careers. 9/4 (1987): 351-360.

[31] Yassin S, Hasan F, Amin W \& Amiruddin N 2008. Implementation of Generic Skills in the Curriculum. Proceedings of the EDU-COM 2008 International Conference on Sustainability in Higher Education: Directions for Change. Edith Cowan University, Perth, Western Australia, 19-21 November 2008

[32] Zaini Ujang 2009. Menjayakan Transformasi: Mewarisi Perjuangan, Memacu Kegemilangan. Siri Perutusan Naib Canselor. Skudai, Johor: Penerbit UTM Press.

[33] Zaki Kamsah 2004. Developing Generic Skills in Classroom Environment: Engineering Students' Perspective in Regional Conference on Engineering Education, Kuala Lumpur: 14-15 December 2004. https://www.academia.edu/5233262/

[34] Zelin M 2016. Empowering Green Education in TVET Through International Project-based Online Competitions.The Online Journal for Technical and Vocational Education and Training in Asia (6). 